\title{
KUALITAS BUTIR SOAL PENILAIAN AKHIR TAHUN MATA PELAJARAN TEKNOLOGI DASAR OTOMOTIF KELAS X TEKNIK KENDARAAN RINGAN OTOMOTIF DI SMK MUHAMMADIYAH GAMPING PERIODE 2018/2019
}

\author{
Yusuf Ardhani* \\ Fakultas Teknik, Universitas Negeri Yogyakarta \\ *Corresponding Author: yusuf.ardhani02@yahoo.com
}

\begin{abstract}
This research aims to determine the quality of the item Final Exam Subjects Automotive Basic Learning Technology Class X TKRO SMK Muhammadiyah Gamping Year 2018/2019 the terms of validity, reliability, level of difficulty, discriminating power and analysis of distractors.This research was quantitative descriptive. Subjects in this research were students of class X TKRO SMK Muhammadiyah Gamping. Data was collected by documentation methode. Data were analyzed using the program ITEMAN Version 4.3. and calculations with the helped of the Microsoft Excel program. The results of this research were: (1) Quality items based on the validity, valid question amounted about 15 items or 37,5\%, while about invalid numbered about 25 item or 62,5\%; (2)Quality items based on the reliability, it can be concluded that item final exam subjects Automotive Basic Learning Technology Class X TKRO SMK Muhammadiyah Gamping Year 2018/2019 school year was not reliable because it had a reliability rate of 0.657; (3) Quality items based on the level of difficulty, which was relatively difficult items totaling 12 points or $30 \%$, items were classified as being a total of 24 items or $60 \%$, and a relatively easy items amounted to 4 items or 10\%; (4) Quality items based on discriminating power, items had distinguishing poor totaling 18 point or $45 \%$, items had discriminating sufficient amounts to 8 grains or as much as $20 \%$, items that have a good discriminating numbered 7 point or by $17,5 \%$ and items which had a negative discriminating totaling 7 items or by 17,5\%; (5) Quality items based on the analysis of effectiveness of distractors, there were 19 items (47,5\%) of good quality, 10 items (25\%) were less good quality, and 11 items (27,5\%) qualified not good.
\end{abstract}

Keywords: quality items, Basic Automotive Technology, SMK Muhammadiyah Gamping.

\begin{abstract}
Abstrak
Penelitian ini bertujuan untuk mengetahui kualitas butir soal Penilaian Akhir Tahun Mata Pelajaran Teknologi Dasar Otomotif Kelas X TKRO di SMK Muhammadiyah Gamping Periode 2018/2019 yang ditinjau dari validitas, reliabilitas, tingkat kesukaran, daya pembeda, dan efektivitas pengecoh.Penelitian ini merupakan penelitian deskriptif kuantitatif. Subjek dalam penelitian ini adalah peserta didik kelas X TKRO SMK Muhammadiyah Gamping. Teknik pengumpulan data dilakukan dengan teknik dokumentasi. Data yang diperoleh dianalisis menggunakan program ITEMAN versi 4.3 dan program Microsoft Excel. Hasil dari penelitian menunjukkan: (1) Kualitas soal berdasarkan validitas, soal valid berjumlah 15 soal atau $37,5 \%$ sedangkan soal tidak valid berjumlah 25 soal atau $62,5 \%$; (2) Kualitas soal berdasarkan reliabilitas, dapat disimpulkan butir soal Penilian Akhir Tahun mata pelajaran Teknologi Dasar Otomotif kelas X TKRO SMK Muhammadiyah periode 2018/2019 memiliki koefisien reliabilitas rendah sebesar 0,657; (3) Kualitas soal berdasarkan tingkat kesukaran, butir tergolong sukar berjumlah 12 butir atau 30\%, butir soal tergolong sedang/cukup berjumlah 24 butir atau $60 \%$, dan butir soal yang tergolong mudah berjumlah 4 butir atau $10 \%$; (4) Kualitas soal berdasarkan daya pembeda, butir soal memiliki daya pembeda jelek berjumlah 18 butir atau sebesar $45 \%$, butir soal yang memiliki daya pembeda cukup berjumlah 8 butir atau sebanyak $20 \%$, butir soal yang memiliki daya pembeda baik berjumlah 7 butir atau sebesar 17,5\% dan butir soal yang memiliki
\end{abstract}




\section{Yusuf Ardhani}

daya pembeda negatif berjumlah 7 butir soal atau sebesar 17,5\%; (5) Kualitas soal berdasarkan analisis efektivitas pengecoh, terdapat $19(47,5 \%)$ butir soal berkualitas baik, sebanyak 10 (25\%) butir soal berkualitas kurang baik dan 11(27,5\%) berkualitas jelek.

Kata kunci: Kualitas Butir Soal, Teknologi Dasar Otomotif, SMK Muhammadiyah Gamping.

\section{PENDAHULUAN}

Pendidikan merupakan suatu usaha untuk memperbaiki kualitas seseorang dalam bidang akademik maupun non akademik. Kualitas dapat dilihat salah satunya dari keberhasilan seorang guru dalam melakukan pembelajaran. Proses pembelajaran yang baik menghasilkan hasil yang baik, begitupun juga sebaliknya apabila proses pembelajaran tidak baik maka hasilnya juga tidak baik. Hasil belajar ditandai dengan pemahaman siswa terhadap materi yang dipelajari.

Proses pembelajaran tidak pernah terhindar dengan penilaian. Penilaian berguna untuk mengukur keberhasilan pembelajaran yang telah dilakukan oleh guru. Penilaian juga dapat berguna untuk melihat kekurangan dari proses pembelajaran sehingga dapat diperbaiki lagi di pembelajaran berikutnya. Penilaian dapat dilakukan dengan berbagai teknik salah satunya adalah teknik tes dan non tes.

Penilaian pada dasarnya bertujuan untuk mengetahui atau mendapatkan umpan balik dari tujuan atau kompetensi yang telah dibuat oleh guru. Penilaian hasil belajar berdasarkan kurikulum dibagi menjadi tiga ranah yaitu ranah pengetahuan (kognitif) dapat dilakukan dengan menggunakan tes tertulis ataupun lisan, ranah keterampilan (psikomotorik) dapat dilakukan dengan praktik, dan ranah sikap (afektif) dapat dilakukan dengan cara observasi dan penilaian teman sejawat. Ranah kognitif paling dominan digunakan untuk mengukur pemahaman siswa. Berbagai cara dapat dilakukan untuk mengetahui keberhasilan siswa dalam ranah kognitif salah satunya dengan cara menguji siswa untuk mengerjakan soal. Soal yang baik harus memenuhi validitas, reliabilitas, tingkat kesukaran, daya pembeda, dan efektifitas pengecoh. Validitas berkenaan dengan ketetapan alat penilaian terhadap konsep yang dinilai sehingga betul-betul menilai apa yang seharusnya dinilai (Sudjana, 2013; Purnama \& Martubi, 2017). Reliabilitas merupakan tingkat atau derajat konsistensi dari suatu alat pengukur atau instrumen (Arifin, 2017: 258). Sebuah instrumen dikatakan memiliki tingkat reliabilitas yang tinggi apabila dapat menghasilkan data yang hampir sama ketika dicoba berkali-kali. Tingkat kesukaran soal merupakan pengukuran seberapa besar derajat kesukaran soal. Suatu soal dikatakan baik, apabila memilki tingkat kesukaran soal yang seimbang (proporsional) dalam artian soal tersebut tidak terlalu mudah atau terlalu sukar (Arifin, 2017: 266). Daya pembeda adalah pengukuran sejauh mana suatu butir soal mampu membedakan peserta didik yang sudah menguasai kompetensi dengan peserta didik yang belum/kurang menguasai kompetensi berdasarkan kriteria tertentu (Arikunto, 2013: 235). Distraktor yaitu suatu pola yang dapat menggambarkan 
bagaimana siswa menentukan pilihan jawabannya terhadap kemungkinan - kemungkinan yang telah dipasangkan pada setiap butir item (Sudijono, 2012: 387).

Berdasarkan hasil observasi di SMK Muhammadiyah Gamping pada tanggal 13 November 2019 soal yang digunakan dalam Penilaian Akhir Tahun (PAT) mata pelajaran Teknologi Dasar Otomotif kelas X Teknik Kendaraan Ringan Otomotif merupakan soal berbentuk pilihan ganda. PAT merupakan hal yang sangat penting, karena untuk mengukur sejauh mana siswa paham terhadap materi yang telah diajarkan sehingga membutuhkan soal yang berkualitas. Soal yang berkualitas adalah soal yang memenuhi kriteria soal yang baik. Soal yang digunakan dalam ujian dibuat oleh guru pengampu dan belum pernah dilakukan analisis secara kuantitatif menyeluruh.

Berdasarkan uraian tersebut maka dilakukan penelitian dengan judul "Kualitas Butir Soal Penilaian Akhir Tahun Mata Pelajaran Teknologi Dasar Otomotif Kelas X Teknik Kendaraan Ringan Otomotif di SMA Muhammadiyah Gamping Periode 2018/2019” bertujuan untuk mengetahui kualitas butir soal.

\section{METODE}

Jenis penelitian yang dilakukan adalah penelitian deskriptif kuantitatif. Penelitian deskriptif kuantitatif adalah penelitian yang bertujuan untuk menggambarkan suatu fenomena yang ada secara verbal atau dengan kalimat dan angka-angka yang sedang berlangsung atau di masa sebelumnya (Syaodih, 2012: 53).

Penelitian dilakukan pada 13-20 Januari 2020 di SMK Muhammadiyah Gamping di Jl. Wates KM 6, Depok, Ambarketawang, Gamping, Kabupaten Sleman, DIY pada kelas X semester Genap pada Tahun Ajaran 2019/2020.

Subjek pada penelitian ini adalah seluruh siswa kelas X TKRO di SMK Muhammadiyah Gamping dan Objek dalam penelitian ini adalah soal Penilaian Akhir Tahun mata pelajaran Teknologi Dasar Otomotif Kelas X TKRO di SMK Muhammadiyah Gamping. Teknik sampling yang digunakan adalah teknik sampling jenuh. Menurut Sugiyono (2016: 85) menyatakan bahwa sampling jenuh adalah teknik sampling apabila seluruh anggota populasi digunakan sebagai sampel.

Teknik pengumpulan data yang digunakan adalah teknik dokumentasi dan observasi. Teknik observasi adalah cara mengumpulkan data dengan melakukan pengamatan (Sugiyono, 2016; Windarto \& Martubi, 2017). Instrumen yang digunakan adalah soal dan lembar jawab serta kartu telaah soal bentuk pilihan ganda. Teknik analisis data dengan pendekatan kuantitatif. Pendekatan kuantitatif dibantu dengan software Microsoft Excel dan ITEMAN versi 4.3. 


\section{HASIL DAN PEMBAHASAN}

\section{Analisis Kuantitatif}

\section{a. Analisis Validitas}

Tabel 1. Hasil analisis validitas

\begin{tabular}{rrr}
\hline Kategori & Jumlah & \multicolumn{1}{c}{ Presentase } \\
\hline Valid & 15 & $37,5 \%$ \\
Tidak valid & 25 & $62,5 \%$
\end{tabular}

Berdasarkan hasil analisis Validitas dapat terlihat di SMK Muhammadiyah Gamping memiliki soal dinyatakan valid sebesar $(37,5 \%)$ sedangkan soal dinyatakan tidak valid sebesar $(62,5 \%)$. Berdasarkan hasil analisis tersebut dapat terlihat bahwa dimana pada soal yang digunakan masih memiliki validitas rendah, dalam butir soal Penilaian Akhir Tahun tersbut adalah soal yang dibuat oleh guru pengampu. Hal tersebut sesuai dengan pendapat Arifin (2014: 248) menyatakan bahwa salah satu faktor yang mempengaruhi

validitas adalah faktor jawaban dari siswa. faktor tersebut meliputi kecepatan siswa dalam menjawab secara cepat tetapi jawaban tersebut tidak benar dan siswa dalam menjawab soal dengan coba-coba tanpa memikirkan jawaban yang paling benar.

Menurut Rahayu dan Dzajari (2016: 91) tindak lanjut terhadap hasil analisis validitas butir soal sebagai berikut:

a. Butir soal yang valid dapat digunakan kembali pada tes berikutnya atau disimpan pada bank soal.

b. Butir soal yang tidak valid diperbaiki disesuaikan dengan indikator pencapaian maupun disesuaikan dengan teknik penyusunan butir soal.

\section{b. Reliabilitas}

Tabel 2. Hasil analisis reliabilitas

\begin{tabular}{cc}
\hline Kategori & Jumlah \\
\hline Reliabiltas & 0,657
\end{tabular}

Berdasarkan hasil analisis, hasil indeks reliabilitas di SMK Muhammadiyah Gamping sebesar (0,657). Menurut Arifin (2017: 259) menyatakan bahwa salah satu faktor yang mempengaruhi reliabilitas adalah objektivitas. Objektivitas disini maksudnya adalah setiap siswa mempunyai kemampuan yang berbeda-beda, sehingga hasil dapat berbeda pula. Hal tersebut juga selaras dengan pendapat Scarvia yang menyatakan bahwa untuk mendapatkan hasil reliabilitas yang ajeg atau tetap memang sulit karena dipengaruhi oleh unsur kejiwaan 
manusia meliputi kemampuan dan kecakapan yang berubah-ubah dari waktu ke waktu (Arikunto, 2013: 101).

Berdasarkan hasil dari validitas dan reliabilitas dapat terlihat bahwa adanya hubungan antara keduanya, pada SMK Muhammadiyah Gamping memiliki nilai validitas rendah dan reliabilitas rendah juga. Menurut Arikunto (2013: 101) menyatakan bahwa sebuah tes mungkin reliabel tetapi tidak valid atau sebaliknya sebuah tes yang valid biasanya reliabel. Hal tersebut membuktikan bahwa nilai validitas yang rendah akan menghasilkan nilai reliabilitas yang rendah pula, begitupun sebaliknya nilai validitas yang tinggi akan menghasilkan nilai reliabilitas yang tinggi. Menurut Zein, dkk (2013: 46) menyatakan bahwa validitas butir memiliki hubungan dengan reliabilitas, dimana semakin banyak jumlah butir yang valid, semakin besar pula koefisien reliabilitas suatu tes.

Berdasarkan uraian tersebut, soal Penilaian Akhir Tahun mata pelajaran Teknologi Dasar Otomotif kelas X TKRO di SMK Muhammadiyah Gamping Tahun Ajaran 2018/2019 memiliki kualitas yang rendah dari segi reliabilitasnya (un-reliable). Hal ini sesuai dengan pendapat Arifin (2017: 259) yang menyatakan bahwa tes reliabel adalah apabila koefisien yang tinggi dan kesalahan baku pengukuran (standard error of measurenment) rendah. Menurut Arikunto (2013: 101-102) salah satu cara untuk menaikkan nilai reliabilitas adalah dengan cara menambah jumlah butir soal, misal dari 40 soal ditambah 20 soal sehingga menjadi 60 soal dimana akan menambah nilai reliabilitas sebesar 0,09.

\section{c. Tingkat Kesukaran}

Tabel 3. Hasil analisis tingkat kesukaran

\begin{tabular}{clc}
\hline Kategori & Jumlah & Presentase \\
\hline Terlalu Mudah & 4 & $10 \%$ \\
Cukup & 24 & $60 \%$ \\
Terlalu Sukar & 12 & $30 \%$
\end{tabular}

Hasil analisis dari Tingkat Kesukaran butir soal Penilaian Akhir Tahun mata pelajaran Teknologi Dasar Otomotif kelas X TKRO di SMK Muhammadiyah Gamping sebanyak 4 butir soal dikategorikan terlalu mudah $(\mathrm{P}=0,70-1,0)$ dengan persentase $10 \%, 24$ butir soal termasuk kategori cukup $(\mathrm{P}=0,30-0,70)$ dengan persentase $60 \%$, dan untuk kategori terlalu sukar $(\mathrm{P}=$ 0,00-0,30) sebanyak 12 butir soal dengan persentase $30 \%$.

Berdasarkan uraian tersebut soal Penilaian Akhir Tahun mata pelajaran Teknologi Dasar Otomotif kelas X TKRO di SMK Muhammadiyah Gamping Tahun Ajaran 2018/2019 memiliki tingkat kesukaran yang cukup berkualitas. Menurut Arifin (2014: 270-271) untuk memperoleh 


\section{Yusuf Ardhani}

prestasi belajar yang maksimal maka proporsi tingkat kesukaran soal harus tersebar secara normal, seperti $25 \%$ soal sukar, $50 \%$ soal sedang atau cukup, $25 \%$ soal mudah.

Menurut. Sudijono (2011: 376) tindak lanjut yang perlu dilakukan setelah analisis item tingkat kesukaran adalah sebagai berikut:

a Butir item tingkat kesukaran berdasarkan hasil analisis dalam kategori baik (tingkat kesukaran cukup atau sedang), sebaiknya butir item tersebut disimpan dalam bank soal. Selanjutnya butir soal tersebut dapat digunakan lagi pasa tes berikutnya.

b. Butir item tingkat kesukaran berdasarkan analisis dalam kategori terlalu sukar ada 3 kemungkinan tindak lanjut yaitu:

1) Butir item tersebut dibuang dan tidak akan dikeluarkan lagi dalam tes selanjutnya.

2) Diteliti ulang dan ditelusuri faktor yang menyebabkan butir item soal sulit dijawab oleh peserta didik. Setelah mengetahui faktornya maka dapat dilakukan perbaikan dengan cara menyederhanakan lagi supaya mudah dipahami oleh peserta didik. Setelah diperbaiki maka soal dapat digunakan lagi di tes selanjutnya.

3) Butir item masih dapat diambil manfaatnya dalam tes-tes yang sifatnya ketat. Dalam arti sebagian besar dari testee tidak akan diluluskan dalam seleksi tersebut.

c. Butir item tingkat kesukaran berdasarkan hasil analisis dalam kategori terlalu mudah, ada 3 kemungkinan tindak lanjut yaitu:

1) Butir item soal tersebut dibuang dan tidak akan digunakan lagi di tes selanjutnya.

2) Diteliti ulang dan ditelusuri faktor apa saja yang membuat peserta didik terlalu mudah untuk menjawabnya. Setalah diketahui faktornya, maka dapat dilakukan revisi terhadap butir item soal sehingga dapat digunakan lagi di tes berikutnya.

3) Butir item yang termasuk dalam kategori mudah ini dapat dimanfaatkan pada tes yang sifatnya longgar. Bisa dikatakan hanya sebagai formalitas saja.

\section{d. Daya Pembeda}

Tabel 4. Hasil analisis daya pembeda

\begin{tabular}{ccc}
\hline Kategori & Jumlah & Presentase \\
\hline Sangat Baik & 0 & $0 \%$ \\
Baik & 7 & $17,5 \%$ \\
Cukup & 8 & $20 \%$ \\
Jelek & 18 & $45 \%$
\end{tabular}

Hasil analisis dari Daya Pembeda butir soal Penilaian Akhir Tahun mata pelajaran Teknologi Dasar Otomotif kelas X TKRO di SMK Muhammadiyah Gamping sebanyak 7 butir soal dikategorikan baik (Rpbis $=0,41-0,70$ ) dengan persentase 17,5\%, 8 butir soal 
dikategorikan cukup (Rpbis = 0,21-0,40) dengan persentase 20\%, 18 butir soal dikategorikan jelek (Rpbis $=0,00-0,20)$ dengan persentase 45\%, 7 soal dinyatakan sangat jelek (Rpbis = Negatif) dengan persentase $17,5 \%$, sedangkan tidak terdapat butir soal yang masuk dalam kategori sangat baik.

Berdasarakan hasil tingkat kesukaran dan daya pembeda dapat terlihat bahwa tingkat kesukaran mempengaruhi nilai daya pembeda. Menurut Suharsimi Arikunto (2013: 233) hubungan tingkat kesukaran $(\mathrm{P})$ dengan daya pembeda $(\mathrm{D})$ dapat dilihat dari rumus $\mathrm{D}=2 \mathrm{P}$. Berdasarakan teori tersebut maka hasil analisis yang telah dilakukan sesuai dengan teori tersebut. Menurut Zein, dkk (2017: 43) satu indeks kesukaran pada satu butir soal berpeluang memiliki beberapa indeks daya pembeda. Suatu soal yang memiliki tingkat kesukaran dengan kategori sukar, belum dapat dipastikan memiliki suatu item dengan tingkat kesukaran tertentu. Menurut Arikunto (2013: 233) menyatakan bahwa nilai tingkat kesukaran yang dianjurkan adalah antara 0,30 dan 0,70, namun perlu bahwa soal-soal tersebut tidak berarti mempunyai nilai daya pembeda yang tinggi. Berdasarkan uraian tersebut soal Penilaian Akhir Tahun mata pelajaran Teknologi Dasar Otomotif kelas X TKRO di SMK Muhammadiyah Gamping Tahun Ajaran 2018/2019 memiliki daya pembeda yang kurang berkualitas karena masih banyak butir soal yang di kategorikan jelek masih lebih tinggi dibandingkan yang kategori baik.

Menurut Sudijono (2015: 408-409) tindak lanjut butir soal setelah dilakukan analisis daya pembedanya adalah sebagai berikut:

a. Butir item dengan daya pembeda baik disimpan dalam bank soal. Butir item dapat digunakan kembali untuk tes hasil belajar mendatang.

b. Butir item dengan daya pembeda rendah, ada dua kemungkinan tindak lanjut yaitu: dilakukan revisi lalu kemudian digunakan kembali untuk tes mendatang atau dibuang.

c. Butir item yang angka indeks diskriminasinya bertanda negatif, sebaiknya dibuang karena kualitas butir soalnya sangat jelek.

\section{e. Pengecoh (Distraktor)}

Tabel 5. Hasil analisis pengecoh

\begin{tabular}{cll}
\hline Kategori & Jumlah & Presentase \\
\hline Baik & 19 & $47,5 \%$ \\
Kurang Baik & 10 & $25 \%$ \\
Jelek & 11 & $27,5 \%$ \\
\hline
\end{tabular}

Hasil analisis dari Efektifitas Pengecoh butir soal Penilaian Akhir Tahun mata pelajaran Teknologi Dasar Otomotif kelas X TKRO di SMK Muhammadiyah Gamping dengan jumlah sebanyak 19 butir soal dikategorikan baik (IP $\geq 2,5 \%=$ diterima) dengan persentase $47,5 \%, 10$ 


\section{Yusuf Ardhani}

butir soal dikategorikan kurang baik $(0 \% \leq \mathrm{IP} \leq 2,5 \%=$ direvisi) dengan persentase $25 \%$, dan 11 butir soal dikategorikan jelek (IP=0\% = ditolak) dengan persentase $27,5 \%$.

Distraktor dikatakan berfungsi dengan baik apabila dipilih sekurang-kurangnya 2,5\% dari peserta tes atau bernilai 0,025 . Keberfungsian soal efektif apabila seluruh distraktor pada satu soal berfungsi dengan baik. Berdasarkan hasil analisis tersebut dapat terlihat bahwa hasil baik (diterima) sebesar 47,5\% ,cukup tinggi namun soal belum bisa dikatakan baik karena belum lebih dari 50\% atau masih dibawah jumlah keseluruhan soal untuk efektifitas pengecohnya. Menurut Arikunto (2013: 234) menyatakan bahwa salah satu penyebab distraktor tidak berfungsi dengan baik adalah terletak pada rumusan kalimatnya, sehingga perlu dilakukannya penulisan kembali dengan perubahan yang seperlunya saja.

Menurut Zulaiha (2008: 18) tindak lanjut setelah dilakukan analisis keefektifan distraktor sebagai berikut ini:

a. Distraktor diterima karena sudah baik, artinya semua distraktor pada soal sudah dipilih $2,5 \%$ dari peserta tes.

b. Distraktor ditulis kembali karena kurang baik, artinya distraktor belum menjalankan fungsinya dengan baik (distraktor dipilih kurang dari 2,5\%).

c. Ditolak karena tidak baik, artinya distraktor sama sekali tidak dipilih peserta tes $(0 \%)$.

\section{SIMPULAN DAN SARAN}

1. Validitas butir soal Penilaian Akhir Tahun Mata Pelajaran Teknologi Dasar Otomotif Kelas X TKRO di SMK Muhammadiyah Gamping Tahun Ajaran 2018/2019 menunjukkan bahwa di SMK Muhammadiyah Gamping memiliki validitas yang kurang baik atau jelek, hal ini dibuktikan soal yang valid sebesar 37,5\% dan soal yang tidak valid sebesar $62,5 \%$.

2. Reliabilitas soal Penilaian Akhir Tahun Mata Pelajaran Teknologi Dasar Otomotif Kelas X TKRO di SMK Muhammadiyah Gamping Tahun Ajaran 2018/2019 memiliki nilai reliabilitas yang jelek, ini dibuktikan nilai reliabilitas di SMK Muhammadiyah Gamping sebesar 0,657 .

3. Tingkat kesukaran butir soal Penilaian Akhir Tahun Mata Pelajaran Teknologi Dasar Otomotif Kelas X TKRO di SMK Muhammadiyah Gamping sebanyak 10\% dengan kategori mudah, 60\% dengan kategori cukup, dan 30\% dengan kategori terlalu sukar.

4. Daya beda butir soal Penilaian Akhir Tahun Mata Pelajaran Teknologi Dasar Otomotif Kelas X TKRO di SMK Muhammadiyah Gamping sebanyak 17,5\% dengan kategori baik, $20 \%$ dengan kategori cukup, 45\% dengan kategori jelek, dan 17,5\% dengan kategori sangat jelek. 
5. Efektivitas pengecoh butir soal Penilaian Akhir Tahun Mata Pelajaran Teknologi Dasar Otomotif Kelas X TKRO di SMK Muhammadiyah Gamping sebanyak 47,5\% dengan kategori baik, 25\% dengan kategori kurang baik, dan 27,5\% dengan kategori jelek.

\section{DAFTAR PUSTAKA}

Arifin, Zainal. 2017. Evaluasi Pembelajaran. Bandung: PT Remaja Rosdakarya.

Arikunto, Suharsimi. 2013. Dasar- dasar Evaluasi Pendidikan. Jakarta: PT Bumi Aksara.

Bagiyono. 2017. Analisis Tingkat Kesukaran dan Daya Pembeda Butir Soal Ujian Pelatihan Radiografi Tingkat 1. Jurnal Widyanuklida. Vol. 16 No. 1, November 2017: 1 - 12. Pusdiklat batan.

Oktanin, Wika Setvi dan Sukirno. 2015. Analisis Butir Soal Ujian Akhir Mata Pelajaran Ekonomi Akuntansi. Jurnal Pendidikan Akuntansi Indonesia. Vol. XIII. No. 1. Tahun 2014. Hal. 35-44. Universitas Negeri Yogyakarta.

Purnama, E. R. D., \& Martubi, M. (2017). ANALISIS BUTIR SOAL UJIAN AKHIR SEMESTER MATA PELAJARAN PEMELIHARAAN SISTEM KELISTRIKAN OTOMOTIF DAN MESIN OTOMOTIF. E-Jurnal Pendidikan Teknik OtomotifS1, 21(1).

Rahayu, Rahmatika dan M. Dzajari. 2016. Analisis Kualitas Soal Pra Ujian Nasional Mata Pelajaran Ekonomi Akuntansi. Jurnal Pendidikan Akuntansi Indonesia. Vol. XIV. No. 1. Yogyakarta: FE UNY.

Sudijono, Anas. 2012. Pengantar Evaluasi Pendidikan. Jakarta: PT Rajagrafindo.

Sudjana, Nana. 2013. Penilaian Hasil Proses Belajar Mengajar. Bandung: PT Remaja Rosdakarya.

Sugiyono. 2016. Metode Penelitian Kuantitatif, Kualitatif, dan R\&D. Bandung: Alfabeta.

Sukiman. 2012. Pengembangan Sistem Evaluasi. Yogyakarta: Insan Madani.

Syaodih, Nana Sukmadinata. 2012. Metode Penelitian Pendidikan. Bandung: PT Remaja Rosdakarya.

Windarto, F., \& Martubi, M. (2017). ANALISIS BUTIR SOAL UJIAN AKHIR SEMESTER GENAP MATA DIKLAT DASAR-DASAR MESIN. E-Jurnal Pendidikan Teknik Otomotif-S1, 19(2).

Zein, Anizam, Rahma Novianti, dan Muhyiatul Fadillah. 2013. Hubungan Antara Validitas Butir, Reliabilitas, Tingkat Kesukaran dan Daya Pembeda Soal Ujian Semester Genap Bidang Studi Biologi Kelas XI SMA/MA Negeri di Kota Padang Tahun Pelajaran 2010/2011. Prosiding. Lampung: FMIPA Universitas Lampung. 
94 Yusuf Ardhani

Zulaiha, Rahmah. 2008. Bagaimana Menganalisis Soal dengan Program ITEMAN.Jakarta:PUSPENDIK 